\title{
Upholding Scientific Duty Amidst Poisonous Disinformation
}

Daniel A. N. Barbosa ${ }^{1}$, Ricardo De Oliveira-Souza ${ }^{2}$, Alessandra Gorgulho ${ }^{3}$, Antonio De Salles ${ }^{4}$

1. Neurosurgery, Stanford University School of Medicine, Stanford, USA 2. Specialized Medicine, The Federal University of the State of Rio de Janeiro, Rio de Janeiro, BRA 3. Neurosurgery, Rede D'or, Sao Paulo, BRA 4. Neurosurgery, University of California, Los Angeles, USA

Corresponding author: Antonio De Salles, a.desalles@yahoo.com

\begin{abstract}
Because of a recent politically-biased Lancet editorial, the world's opinion has been directed against the Brazilian government over the rising numbers of COVID-19 cases in the country. This is an example of reporting data without accounting for important covariates. Epidemiological figures should always be corrected for population size. In fact, Brazil is not even on the list of the 10 countries with the highest number of deaths per 100,000 people. Belgium, the United Kingdom, and Spain are the most affected countries in this regard. The disinformation presented by a renowned medical journal has ignited severe criticisms against a Chief-of-State for not promoting a generalized lockdown in a country of continental size. As scientists, we have a duty to stress the caveats of science instead of fueling political attacks, and we should refrain from jumping to uninformed conclusions without considering well-analyzed data. Moreover, while there is no evidence to endorse the efficacy of a generalized lockdown in socioeconomically vulnerable populations, it is undoubtedly associated with severe nationwide adverse effects.
\end{abstract}

Categories: Quality Improvement, Public Health, Epidemiology/Public Health

Keywords: bias identification, use of evidence in policy making, lockdown, brazil

\section{Editorial}

In a recent Lancet editorial, the world's attention was directed toward the rising numbers of confirmed COVID-19 cases and deaths in Brazil [1]. It highlighted some worrisome projections from studies by the Imperial College, London [1]. During the current global health crisis, articles in renowned medical journals have guided public policies and investments in healthcare [2]. Consequently, scientific information has gained the power to alleviate the suffering of societies; however, disinformation, on the other hand, causes suffering and ruins livelihoods [3].

Brazil is now the country with the second-highest total number of confirmed COVID-19 cases and deaths [4]. Yet, as scientists, we cannot interpret this piece of raw data without accounting for covariates. Brazil has the sixth largest population in the world; therefore, this raw number must be corrected by its population size. It turns out that Brazil has never been among the 10 large countries with the highest number of deaths per

Received 06/17/2020

Review began 06/21/2020 Review ended 07/14/2020 Published 07/22/2020

(c) Copyright 2020

Barbosa et al. This is an open access article distributed under the terms of the Creative Commons Attribution License CC-BY 4.0., which permits unrestricted use, distribution, and reproduction in any medium, provided the original author and source are credited. 100,000 people. That list is headed by Belgium, the United Kingdom, and Spain [4]. As of July 12, 2020, Brazil occupies the 12th spot in that list (Table 1). Such a spurious manner of reporting public health data is completely unacceptable even by the lay media, let alone by a renowned scientific journal $[1,2,4]$. 


\section{Cureus}

\begin{tabular}{|c|c|c|c|}
\hline Country* & Confirmed Cases & Deaths & Deaths/100,000 Population \\
\hline Belgium & 62,469 & 9,782 & 85.64 \\
\hline United Kingdom & 290,504 & 44,883 & 67.50 \\
\hline Spain & 253,908 & 28,403 & 60.79 \\
\hline Italy & 242,827 & 34,945 & 57.83 \\
\hline Sweden & 74,898 & 5,526 & 54.27 \\
\hline France & 208,015 & 30,007 & 44.80 \\
\hline USA & $3,245,925$ & 134,777 & 41.20 \\
\hline Chile & 312,029 & 6,881 & 36.74 \\
\hline Peru & 322,710 & 11,682 & 36.52 \\
\hline Ireland & 25,611 & 1,746 & 35.97 \\
\hline Netherlands & 51,136 & 6,156 & 35.73 \\
\hline Brazil & $1,839,850$ & 71,469 & 34.12 \\
\hline Ecuador & 67,209 & 5,031 & 29.45 \\
\hline Mexico & 295,268 & 34,730 & 27.52 \\
\hline Canada & 109,150 & 8,818 & 23.79 \\
\hline Switzerland & 32,817 & 1,968 & 23.11 \\
\hline Panama & 44,332 & 893 & 21.38 \\
\hline Armenia & 31,392 & 559 & 18.94 \\
\hline
\end{tabular}

\section{TABLE 1: Coronavirus Resource Center: Cases and Mortality by Country[4]}

Updated on Sunday, July 12, 2020, at 03:00 AM EDT

*Countries with $<100,000$ inhabitants are not shown

The Lancet focused on politics instead of a scientific analysis of the pandemic's status in Brazil, an odd choice for a scientific publication. Data not corrected for population size was used to build the claim that "perhaps the biggest threat to Brazil's Covid-19 response is its president", and that "Brazil's leadership has lost its moral compass, if it ever had one" [1]. The editorial failed to provide scientific support, but rather echoed politically-biased ideas. The Lancet's manifesto is merely a science-fueled attack against a Chief-of-State for advising state governors to reopen the economy, and serves instead to encourage a policy of generalized lockdown, which is associated with severe nationwide adverse effects, i.e., increased poverty, conjugal crises, street criminality, depression, suicide, and substance abuse. Calling the lockdown a "sensible measure" contrasts with fair criticisms against leaders embracing policies without sufficient evidence of their efficacy and safety. In fact, the universal lockdown adopted by Brazilian mayors and state governors has not slowed down the growing raw number of COVID-19 cases; instead, it has proven to be extremely harmful to several underserved communities [5]. Indeed, physical distancing and hygiene recommendations are impossible to follow in Brazil's underserved communities, as pointed out by the same editorial [1]. The forceful implementation of these measures has oppressed vulnerable populations, by instilling hunger and crime [5].

It is irresponsible to use poorly analyzed data to accuse leaders, countries, and doctors working with the best of intentions to fight a pandemic that has caused immense misery even in the most developed countries. The use of disinformation to point fingers against those fighting in extremely difficult conditions against the same misery, COVID-19, for the benefit of their underserved people is inhuman and unfair, and the heroes of this pandemic deserve better. The Lancet's Editorial Board should at least publish a note apologizing for these unfounded accusations and lack of sensibility $[1,2,4]$. While we seek to serve the people with a scientific outlook and approaches, a pertinent question arises: When are our colleagues in the medical field going to stop delivering politically-biased disinformation? 


\section{Cureus}

\section{Additional Information}

\section{Disclosures}

Conflicts of interest: In compliance with the ICMJE uniform disclosure form, all authors declare the following: Payment/services info: All authors have declared that no financial support was received from any organization for the submitted work. Financial relationships: All authors have declared that they have no financial relationships at present or within the previous three years with any organizations that might have an interest in the submitted work. Other relationships: All authors have declared that there are no other relationships or activities that could appear to have influenced the submitted work.

\section{References}

1. Editorial (anonymous): COVID-19 in Brazil: “So what?”. Lancet. 2020, 395:1461. 10.1016/S01406736(20)31095-3

2. de Oliveira Andrade R: Covid-19: Brazil now has third highest number of cases behind US and Russia . BMJ. 2020, 369:m2059. 10.1136/bmj.m2059

3. Pacepa IM, Rychlak RJ: Disinformation: Former Spy Chief Reveals Secret Strategies for Undermining Freedom, Attacking Religion, and Promoting Terrorism. WND Books, Washington, DC; 2013.

4. Johns Hopkins University: Coronavirus Resource Center . (2020). Accessed: July 13, 2020: http://coronavirus.jhu.edu/data/mortality.

5. Lockdown puts Brazilian lives at risk. (2020). Accessed: July 13, 2020: http://www.wsj.com/articles/lockdown-puts-brazilian-lives-at-risk-11589743232. 